\title{
Perception and Interpretation of Climate Change among Quechua Farmers of Bolivia: Indigenous Knowledge as a Resource for Adaptive Capacity
}

\author{
$\underline{\text { Sébastien Boillat }}^{1,2}$ and $^{\text {Fikret Berkes }}{ }^{1}$
}

\begin{abstract}
We aim to explore how indigenous peoples observe and ascribe meaning to change. The case study involves two Quechua-speaking farmer communities from mountainous areas near Cochabamba, Bolivia. Taking climate change as a starting point, we found that, first, farmers often associate their observations of climate change with other social and environmental changes, such as value change in the community, population growth, out-migration, urbanization, and land degradation. Second, some of the people interpret change as part of a cycle, which includes a belief in the return of some characteristics of ancient or mythological times. Third, environmental change is also perceived as the expression of "extra-human intentionalities," a reaction of natural or spiritual entities that people consider living beings. On the basis of these interpretations of change and their adaptive strategies, we discuss the importance of indigenous knowledge as a component of adaptive capacity. Even in the context of living with modern science and mass media, indigenous patterns of interpreting phenomena tend to be persistent. Our results support the view that indigenous knowledge must be acknowledged as process, emphasizing ways of observing, discussing, and interpreting new information. In this case, indigenous knowledge can help address complex relationships between phenomena, and help design adaptation strategies based on experimentation and knowledge coproduction.
\end{abstract}

Key Words: adaptive capacity; Andes; Bolivia; indigenous knowledge; perception of climate change; Quechua

\section{INTRODUCTION}

Increases in mean annual temperatures due to climate change will not be distributed evenly across the globe. Instead, some of the largest average temperature increases are indicated for high-mountain ecosystems (IPCC 2007). Glacier retreat is observed in most mountainous areas, including the Andes (Vuille et al. 2008, Bolin 2009). As well, increasing abundance of thermophilic (heat-loving) plants is observed at high elevations (Gottfried et al. 2012). For the people of the Andes, these changes are coming on top of other cultural, political, and economic changes in recent decades. In particular, indigenous and traditional societies have been subjected to the "double exposure" of globalization and global environmental change (Leichenko and O'Brien 2008). In this paper, we focus on climate change observations and interpretations by a group of Quechua-speaking farmers from Bolivia and discuss their implications on processes of change and adaptation.

How vulnerable are indigenous and traditional peoples to climate change, and to global environmental change and globalization in general? What are their relevant adaptations, and what are their prospects to cope with change? Salick and Ross (2009) noted that the IPCC (2007) makes little mention of indigenous peoples, and then only as helpless victims of changes beyond their control. However, many indigenous societies, such as the Inuit, have a historical record of adaptations to the variability of their environments and can hardly be considered helpless (Berkes and Armitage 2010, Nakashima et al. 2012).
Adaptive capacity may be defined as the ability of an individual or group to cope with, prepare for, and/or adapt to disturbance and uncertain social-ecological conditions (Armitage 2005, Smit and Wandel 2006). Adaptive capacity is not the same as adaptation; adaptations are considered manifestations of adaptive capacity and represent ways to reduce vulnerability to change. Four factors have been identified to foster adaptive capacity: (1) learning to live with change and uncertainty, (2) nurturing diversity for reorganization and renewal, (3) combining different types of knowledge for learning, and (4) creating opportunity for selforganization toward social-ecological sustainability (Folke et al. 2003). Adaptive capacity further implies social learning through change and an ability to experiment (Armitage and Plummer 2010, Reed et al. 2010). An important starting point for the capacity to adapt to climate change is the ability to observe and ascribe meaning to changes in the occurrence and intensity of weather phenomena.

Traditional ecological knowledge is a key resource for adaptive capacity (Berkes et al. 2000). We understand traditional ecological knowledge as a knowledge-practicebelief complex, based on multigenerational transmission and cultural continuity, but also as a process open to change (Berkes 2012a). Because climate change is a new and unprecedented phenomenon that has not been previously experienced by indigenous elders, it might be a challenge to traditional knowledge (Berkes 2009). Does it make sense to integrate traditional knowledge into efforts aimed at 
enhancing indigenous people's adaptive capacity? To answer this question, we focus on how people understand or make sense of new observations and unfamiliar experiences. Our hypothesis is that indigenous and traditional peoples use their specific mental models, understood as representations of the world shared by social groups (Lynam and Brown 2011), to observe and interpret climate change.

There is literature regarding local climate change observations and how they are interpreted, from northern regions (e.g., Tyler et al. 2007, Berkes and Armitage 2010, Marin 2010) and from the south (Ovuka and Lindqvist 2000, Raj 2006). In the Andes, there is literature on the threats posed by climate change for small-scale farmers (Bolin 2009, Perez et al. 2010) as well as on locally existing observations and risk management strategies (Tapia et al. 2012). We extend the inquiry further by examining how people interpret change, and the possible implications of their interpretation for adaptive capacity and adaptation strategies.

Andean indigenous peoples have been experts in dealing with climate uncertainty and risk (Perez et al. 2010), significant because climate change is often manifested in terms of increases in variability and in extreme weather events (IPCC 2007). They interpret and react to climate change, drawing on traditional knowledge as well as new technologies. One of the main mechanisms for dealing with risk has been the use of agricultural land as scattered parcels (Campbell and Godoy 1986, Morlon 1992), diversification being a universal risk diffusion strategy (Turner et al. 2003).

Andean indigenous people also have a rich set of indicators used for indigenous ways of predicting the weather, including plant and animal indicators as well as astronomical phenomena (Chirveches 2006, Tapia et al. 2012). Andean ethnoclimatology is relatively well known (Orlove et al. 2002). Numerous generations of indigenous farmers of the Peruvian and Bolivian Andes have gathered in midwinter to observe the Pleiades. If this star cluster appears big and bright, this is understood to predict abundant rains and good harvests the following summer. If the cluster appears small and dim, farmers anticipate poor rains. These predictions are considered strong enough to dictate the choice of crops and areas planted. Orlove and colleagues have shown that Andean ethnoclimatology actually works.

The apparent size and brightness of the Pleiades varies with the amount of thin, high cloud at the top of the troposphere, which in turn reflects the severity of El Niño conditions over the Pacific. Because rainfall in this region is generally sparse in El Niño years, this simple method provides a valuable forecast, one that is as good or better than any longterm prediction based on computer modeling of the ocean and atmosphere (Orlove et al. 2002:428).
Farmer adaptations (Campbell and Godoy 1986) and farmer ethnoclimatology are thus important indicators of the capacity to adapt in the face of uncertainty and change. However, an important, and often overlooked, aspect of the issue is the interpretation of change. We address this gap by focusing on linking traditional knowledge, mental models, and adaptive capacity. We use the example of two villages in the Cochabamba area, Bolivia, to (1) examine how Quechuaspeaking farmers make observations of climate change and what kinds of change they consider significant; (2) explore how they ascribe meaning and interpret climate change; and (3) investigate strategies that they propose to adapt to climate change. The sections of the paper follow these three objectives, and the discussion focuses on how these three components contribute to the capacity of indigenous and traditional peoples to adapt to change.

\section{AREA OF STUDY}

The Central Andes of Bolivia and Peru is the largest high mountain area located at tropical latitudes (Morlon 1992). The rural population of the area belongs mainly to the Quechua and Aymara ethnic groups. In Bolivia, indigenous identities are complex and have played a key role in contemporary politics (Gustafson 2009). Here we focus on a group of Quechua-speaking farmers of the Tunari Mountain Range, Central Bolivia, who simultaneously identify themselves as indigenous and as peasants (campesinos). This group is affiliated with the Confederación Sindical Única de Trabajadores Campesinos de Bolivia (CSUTCB, Unique Conferedation of Peasant Workers Union of Bolivia). CSUTCB is politically close to the government of Evo Morales and has experienced significant empowerment during the last decade (Healey 2009, Bottazzi and Rist 2012).

The Tunari Mountain Range starts at an altitude of $2500 \mathrm{~m}$ (Cochabamba valley) and reaches up to $5000 \mathrm{~m}$ (Tunari Peak), hosting a high variety of microclimatic and topographic features as well as seasonal rainfall with high interannual variability. The valley of Cochabamba hosts the fast growing city of Cochabamba and has an especially dry climate because of the rain shadow of the mountain range that blocks humid air masses coming from the northeast (Navarro and Maldonado 2002). The whole mountain range was declared a National Park in 1991 but with limited implementation (Boillat et al. 2008).

The area has been inhabited by Quechua-speaking farmers since the expansion of the Inca rule in the 15th Century (Wachtel 1981). Until the Bolivian agrarian reform in 1953, the area was divided in large hacienda properties ruled by Spanish-descendent or mestizo landlords who employed indigenous workers under a serfdom system. After the expropriation of the haciendas, land was granted to the indigenous workers who had formed agrarian syndicates. Syndicate members with their families form peasant 
Fig. 1. Location of the area of study with the communities of Chorojo and Tirani.

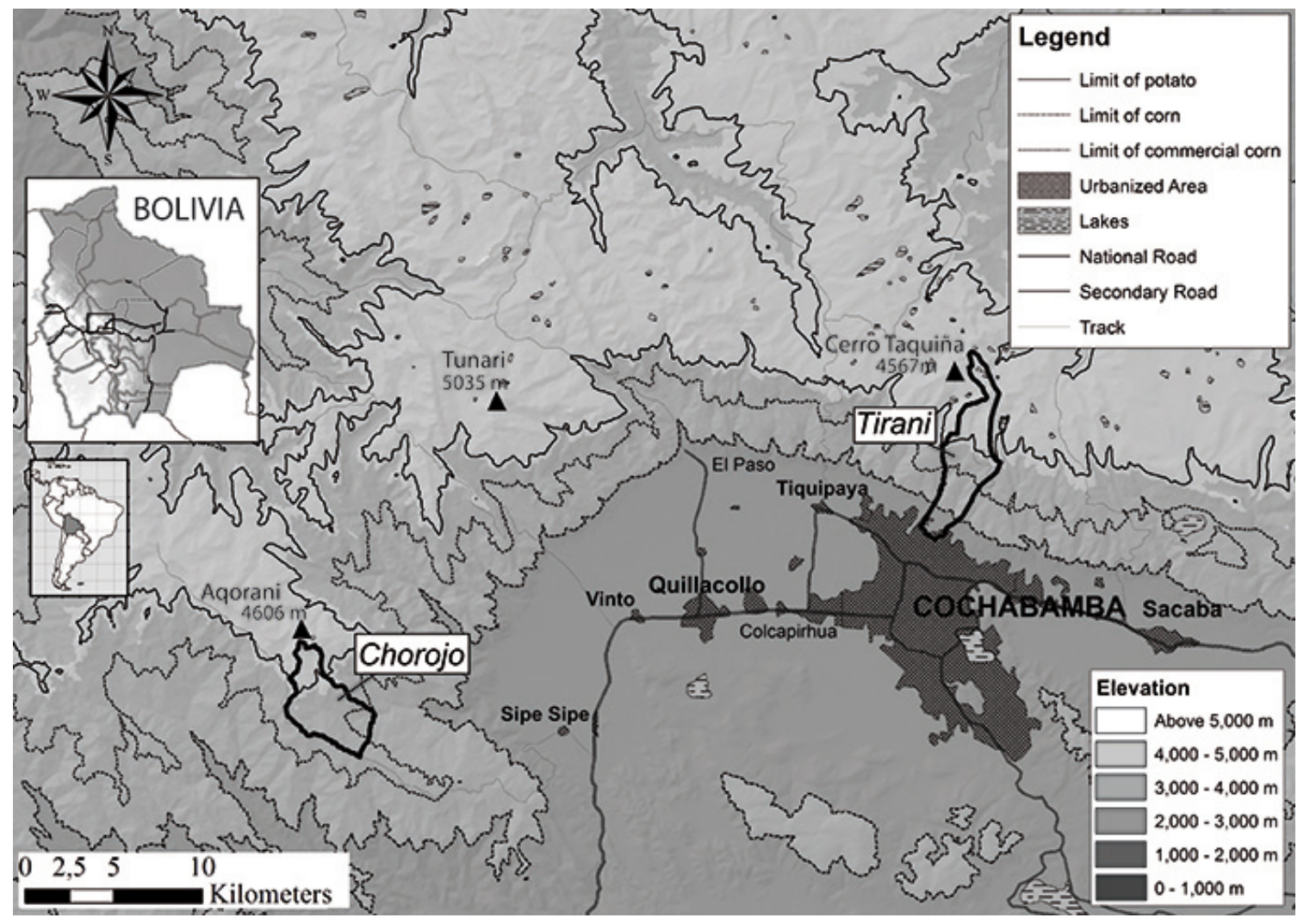

communities, usually scattered settlements, which are the basic social organization units in the area. They own a collective title to a contiguous area of land that they consider their territory.

Farmers in the Tunari Mountains practice small-scale cultivation and livestock breeding at different altitudes. Irrigated fields are mainly located on the mountain slope, between 2600 and $3000 \mathrm{~m}$. There, two harvests can be made in one year, with traditional corn cultivation complemented by cut flowers aimed for city markets. Above $3000 \mathrm{~m}$, cultivation highly relies on seasonal rainfall and is limited by night frost occurring during the winter. At this altitude, only one harvest per year is possible and the main crop is potato, planted in September and harvested in April and May. The farmers never plant potatoes for two consecutive years on the same plot of land. They plant other Andean tubers such as oca (Oxalis tuberosa), ulluco (Ullucus tuberosus), and mashua (Tropaeolum tuberosum) on the second year, and barley, oats, peas, lupine, or lima beans on the third.

Some short-growing and cold-resistant varieties of corn can be grown up to $3600 \mathrm{~m}$, and potatoes can be grown up to 4100 m. After three or four cultivation years, land is fallowed to "let it rest," and grazed with sheep and llamas. Fallow duration varies according to soil fertility, slope, availability of water, and mainly increases with altitude: from 2 to 5 years at 3500 $\mathrm{m}$, to 10 years and more at $3900 \mathrm{~m}$. Although valley people usually cultivate continuous plots, highland households typically work between 6 and 20 small cultivation plots, of between 300 and $2500 \mathrm{~m}^{2}$. Most families use diverse tenure arrangements to access plots, including private property, customary access to communal plots, or sharecropping with wealthier families.

To capture a diversity of views among Tunari Mountains dwellers, we chose to work with two peasant communities representing two ends of a geographical and socioeconomic continuum between rural highland and peri-urban valley farmers (Fig. 1). Chorojo represents the typical rural highland community in the Tunari Mountains, with about 60 households dwelling between 3500 and $3900 \mathrm{~m}$ and a territory with an altitude range from 3400 to $4600 \mathrm{~m}$. Tirani is an example of a peri-urban valley community adjacent to the city's outskirts with about 350 households, and a territory at 2700 to $4500 \mathrm{~m}$, with most people dwelling below $3000 \mathrm{~m}$. 
Table 1. Observed weather changes and their impact in Chorojo.

\begin{tabular}{|c|c|c|}
\hline & Observed changes & Observed impacts \\
\hline Temperature & $\begin{array}{l}\text { - In general the climate is warmer } \\
\text { - More daily temperature extremes } \\
\text { - Frost days are less predictable and come at any } \\
\text { season }\end{array}$ & $\begin{array}{l}\text { - There are too few frost nights in winter to make } \\
\text { dehydrated potatoes (chuño) } \\
\text { - Heat increases the incidence of Andean potato weevil } \\
\text { (Premnotrypes spp) and other pests } \\
\text { - Potatoes can now be cultivated up to } 4,200-4,300 \mathrm{~m} \text {; } \\
\text { but frost can come at any time } \\
\text { - Corn grows better, but often fails because of lack of } \\
\text { rainfall }\end{array}$ \\
\hline Rainfall & $\begin{array}{l}\text { - Rainy season starts later and is less predictable } \\
\text { - Rains concentrate in January and February } \\
\text { - Rainfall comes as "crazy rains," in the form of } \\
\text { storms and with hail } \\
\text { - Hail is more frequent }\end{array}$ & $\begin{array}{l}\text { - Hail causes strong damage to the crops, especially when } \\
\text { potatoes are in flower } \\
\text { - Strong rains wash the soil and provoke landslides, } \\
\text { making land less fertile and difficult to plow }\end{array}$ \\
\hline Wind & $\begin{array}{l}\text { - There is more wind } \\
\text { - Wind direction now comes from the valley }\end{array}$ & - Strong winds from the valley "blow away" the rain \\
\hline Biota & $\begin{array}{l}\text { - Shrubs (Gynoxys glabriuscula, Baccharis } \\
\text { dracunculifolia) and trees (Polylepis subtusalbida) } \\
\text { observed at higher altitudes }\end{array}$ & - Shrub encroachment affects the quality of pastures \\
\hline
\end{tabular}

\section{METHODS}

Research findings build on extensive ethnographic fieldwork carried out in the two communities during 2004-06, with the objective of understanding the use of traditional ecological knowledge in local ecosystem management (Boillat 2007). This study is based on follow-up field work carried out from May to December 2011, with semistructured interviews about people's observations and interpretation of changes in the occurrence and intensity of weather phenomena. Twenty-eight households were selected using the "snowball" technique, 17 in Chorojo and 11 in Tirani. In Tirani, households were selected among those who still farm (about 50 in the community), as main or as secondary activity.

Within each household we focused on "community experts," mostly male household heads but sometimes also women and younger people, who spend most of their time in the community and are most likely to use their knowledge to practice agriculture. Informants (age range 19 to 80) were asked (1) whether they had observed changes in temperature, rainfall, and other weather phenomena; (2) and if so, what changes they observed; and (3) the consequences of these changes on farming. The time frame of changes was not given, but a 10-year period was suggested if asked back. The questions were open-ended, without a list of topics to select from. Thus the topics that came up were the ones spontaneously mentioned by the interviewees. Then they were asked (4) why they think that these changes were occurring and (5) what they were doing to cope with these changes. Finally, the households involved also produced land use maps (following Tobias 2000), locating the history of their productive activities on a map of the community territory.
Results were then discussed and validated at the monthly community meetings.

\section{RESULTS}

\section{Local observations of climate change and its impact}

All but two interviewed households stated that the climate has become warmer during the last two decades (Table 1, 2). In Chorojo, where potato cultivation is more important, people were concerned by the increased incidence of potato insect and fungi pests that they attributed to warmer temperatures, but also to air pollution, soil fertility loss, and increased use of pesticides.

People from the higher areas of both communities have noticed a decrease in the number and intensity of frost nights during the winter. One of the consequences is the difficulty to process potatoes into chuño, a freeze-dried product that requires exposure to alternative night frosts and intense day sunlight for one to two weeks. If the cold is not intense enough, potatoes dry up instead of freezing and spoil, as happened to some families in 2011. Nevertheless, some people also noticed an increase of summer temperatures, and a few also acknowledged the advantage of sowing crops in higher areas. After 2004, the community of Chorojo started to open small areas of potato cultivation at $4150 \mathrm{~m}$. Moreover, pasture lands between 4100 and $4300 \mathrm{~m}$ were distributed among all community members to be cultivated in the near future. Two households mentioned that they increased their corn or pea cultivation at their upper limits. In Tirani, a family dwelling at $4000 \mathrm{~m}$ started to sow cut flowers and established some potato plots at $4200 \mathrm{~m}$. The farmer involved stated: 
Table 2. Observed weather changes and their impact in Tirani.

\begin{tabular}{|c|c|c|}
\hline & Observed changes & Observed impacts \\
\hline Temperature & $\begin{array}{l}\text { - In general the climate is warmer } \\
\text { - There are less nights with frost in the winter } \\
\text { - Highland ponds do not freeze any more in winter }\end{array}$ & $\begin{array}{l}\text { - Less frost nights make it possible to cultivate corn and } \\
\text { cut flowers in higher areas, and open up potato cultivation } \\
\text { at } 4200 \mathrm{~m} \\
\text { - In the valley, strong sunshine harms the plants and } \\
\text { increases pests } \\
\text { - Heat makes cattle aggressive }\end{array}$ \\
\hline Rainfall & $\begin{array}{l}\text { - Total annual rainfall diminished } \\
\text { - Rainy season starts later or is less predictable } \\
\text { - Interannual variability in rainfall has increased } \\
\text { - Rains are stronger and distribution is more uneven }\end{array}$ & $\begin{array}{l}\text { - Water availability diminished } \\
\text { - Higher reliance on irrigation system } \\
\text { - Alternance of rain and heat during the day harm the } \\
\text { plants }\end{array}$ \\
\hline $\begin{array}{l}\text { Wind } \\
\text { Biota }\end{array}$ & $\begin{array}{l}\text { - Wind comes now form the north and the east } \\
\text { - Weeds and shrubs grow faster }\end{array}$ & $\begin{array}{l}\text { - Rainfall coming from the northeast is more beneficial } \\
\text { - Weeds harder to remove from crops }\end{array}$ \\
\hline
\end{tabular}

It is the limit; there are no more crops in higher areas. In this place crops did not produce before. In recent times crops are producing here. This is because in past times the cold did not let the crops grow. (M, aged 62, Tirani)

Other people, however, pointed out that temperature extremes have increased, with higher thermal amplitude within a season. Thus sowing in higher areas is still highly risky because of night frosts. Most villagers of both communities expressed more concerns about the distribution and predictability of rainfall, rather than about the total amount of rainfall. The beginning of the rainy season is especially relevant in rain-fed cultivation because early rains are necessary to enable early potato plantation. Thus one main concern was that rainfall now concentrates in January and February when it should be more evenly distributed from end of September to beginning of March. A villager from Tirani expressed the following:

Everything changed. It is not like before. Here at least, the weather was good twenty years ago. Now since then everything changed, for example the rains don't come in their right time, it's not the season, and it varies a lot. (M, aged 47, Tirani)

People from Chorojo were also concerned by the incidence of hail, which increases with altitude and can destroy entire crops. Hail comes together with "crazy rains" (loco paras), which are violent storms that have become more frequent. They considered hail as especially critical in December and January, when potatoes start flowering and tuber building. Farmers from Chorojo stated the following:

The weather has changed too much, there is more heat and more wind, there are crazy rains and it is harmful. Very clumsy rains come, and hail falls. The weather is not good like before, it harms the crops. (M, aged 80, Chorojo)
Before, the rains were quiet, smoother and very constant. It was not like now, these crazy rains that make rivers everywhere. There is hail as well. (M, aged 72 , Chorojo)

An additional concern about violent rains was that they increase soil erosion. Some households from Chorojo spontaneously mentioned an overall decrease in land productivity due to soil erosion. People said the risk of erosion is especially high when rains start late, leaving the soil with poor vegetation cover, thus making it more vulnerable.

\section{Observing the weather}

Because rain-fed cultivation is highly dependent on rainfall patterns, the farmers have to make crucial decisions about sowing time, location of cultivation plots, and the varieties of crops used. In both Tirani and Chorojo, people make these decisions on the basis of their observations of what they call the "signs of weather" (señas del tiempo). Traditional knowledge on weather prediction was recorded during the fieldwork, consistent with earlier studies (see Chirveches 2006). People observed for example the location of the eggs of the leuque leuque (Vanellus resplendens, Andean lapwing) or the flowering patterns of Berberis commutata to predict the abundance of rain. These indicators were still used despite changes in weather patterns; most people thought that they were still valid but need to be reassessed and observed more carefully.

While some indicators like the form and color of clouds or animal behavior were used to predict short-term weather changes, there were also long-term indicators observed during the winter (June to August) to predict the coming rain season. One of them was the brightness of the Pleiades (Orlove et al. 2002) which is known and used by several people in Chorojo and Tirani, but many other indicators were used as well, as the following statements show: 
In August ..., when Antonio [nickname of the Andean fox, Lycalopex culpaeus] goes down [to the river] and howls, it is a sign for a good year, if he howls normally it is a good sign, when it is for a bad year, he does not go down, he only walks on the hilltops, and he howls intermittently. (M, aged 37, Chorojo)

For the rainy season, there is an important secret to know if it will rain or not, in the stone. ... Stones sweat like humans do. So, when it has a couple of flakes, like snow, that year will have a good rain.... In the month of August, you have to watch the stone's temperature. ... You have to see its temperature, it attracts the time of heat. Then when there is much heat, it will not sweat any more, the heat dries it up. (M, aged 70, Tirani)

The major decision in using long-term prediction was the time to plant potatoes. When asked what to do if a good or bad year is predicted, a villager from Chorojo answered:

I look at the flowers of the muña [Clinopodium bolivianum]. ... It starts [to flower] in August, just before September which is the time to plant potatoes. So if flowers are well clustered, it is going to be a good year, and it flowers abundantly. ... If the muña flowers well, I can start sowing tomorrow, and next day, and over next day. (M, aged 42, Chorojo)

When we asked what happened if the muña does not flower abundantly, the answer was:

... then [you do] not [have to sow] the day after the other. One has to wait for a week between each sowing. Then when the potato flowers, rainfall must come, but sometimes the rain gets lost, so the harvest might be lost, but I have the other plot that flowers later. (M, aged 42, Chorojo)

If a "bad year" is predicted, people assume a more prudent attitude and spread their sowings temporally to cope with the perceived higher risk of drought. Therefore, the long-term observation of weather indicators plays a key role in taking crucial decisions.

\section{Interpretations of change}

Answers to the question "why do they think that these changes are occurring" were diverse and showed how people interpret change. The first three statements come from Chorojo:

Before there used to be more respect [for our customs], now there is no respect, this is why the weather has changed as well. If it stays like this, things are going to be worse. (F, aged 57, Chorojo)

I don't like this change ... there is more hail, more rain, unexpected cold or strong heat. This is due to people's bad lives, their infidelities, everybody behaves badly and therefore these things come. For example, in the community some people brought skulls to practice witchcraft. This makes the Pachamama get angry and she does not want to provide us with food any more. (M, aged 24, Chorojo)

It seems that, as the "brothers" (people converted to evangelical groups) announced: there will be heat, rains, and landslides; it seems that this is truly happening. This may be the Final Judgment. ... Probably in the Bible it is like this, I am thinking about that. (M, aged 37, Chorojo)

The first two statements refer to a loss of values that are not necessarily environmental. They show that some people attribute climate change to different causes than do scientists, and that they postulate a direct relationship between values and climate. The second statement's causal explanation refers more specifically to the mood of the Pachamama, the maternal creator-figure linked with crop production (Van den Berg 1990), that is thought to directly respond to human behavior with reward or punishment. The third statement refers to interpretations promoted by some Christian Evangelical movements, seeing environmental changes as signs of a coming apocalypse, the ultimate response of God to inappropriate human behavior.

People from Tirani associated climate change more directly with environmental behavior:

It changes, I don't know, it should be like they say, the "systematic change" (cambio sistematico), the pollution, all these factors are the cause. It is visible, now heat is more intense. (M, aged 50, Tirani)

If I am correct it is because of our own hands, we harm it, from above, and this happens. With the cars and everything. (M, aged 26, Tirani)

The first statement shows that the speaker knows about climate change, but he interprets it in a broader way, considering that factors are many and everything is changing. The second statement makes the link between environmental behavior and climate change, but does not ascribe the main cause to the industrialized countries and those that emit more greenhouse gases. Rather, its author considers his community as also being responsible for the change.

Some statements, two from Tirani and one from Chorojo, also expressed the idea of present change referring back to what already happened in the past:

Some years there is a lot of rain, some years there is none. Thus, it seems that every 100 years the weather changes. (M, aged 62, Tirani)

I believe that the weather is doing roundtrips to other planets; I think it is like this. It went to the corner [of the mountain], because now the rain 
comes from the North, and from the East as well. (M, aged 56, Tirani)

These lands [above $4100 \mathrm{~m}$ ] are what the Incas left behind; these lands are very fertile; it must have been like that before; there must have been houses there. Now, what was before has turned over to us. (F, aged 40, Chorojo)

These quotes show that some people perceive climate change not necessarily as an unprecedented phenomenon but as possibly cyclic. They believe that some characteristics of ancient times, like the Inca rule in the case of Chorojo, could be coming back.

Finally, some statements, all from Tirani, also show how people interpret specific weather phenomena:

When hail falls, people say: 'Hail falls because of someone's fault.' It is a punishment, and I think it must be so ... (F, aged 40, Tirani)

Down there, by the crossroads, there is a hole. Sometimes when the sun is setting you can hear there a baby crying. We say that it is because they used to bury aborted babies there. Then, hail rises from there. And hail also affects the burned parts. It also affects places which are half burned. It is truly punishment. (M, aged 70, Tirani)

The lakes get angry, as do the mountains, when we approach a lake when there are no human people.... Vapors rise from the lakes, or hail falls, or cold or wind comes. But when the lakes are tame, in that case nothing happens. (M, aged 70, Tirani)

From that side it (the rain) came before, but now since they opened the mine, bye, the rain disappeared ... That place was always mean. And they forced it to be good. It was a mean place, it got angry, so it was, now it is tame. (M, aged 24, Tirani)

The four statements share the idea that weather phenomena can occur as a reaction of an "extra-human intentionality." Hail is often considered a punishment from God or the Pachamama in response to inappropriate human behavior. The belief also exists in Chorojo: after a strong hail event, the families with daughters who had (secretly) performed abortions were obliged to pay for the crop damage due to hail.

The last two statements also show that not only God or Pachamama can become angry; according to people's beliefs, a lake can also intentionally provoke hail or storms. A common belief is that places where there are no "human people" become angry when someone approaches them. The emphasis on "human people" means that other kinds of "people" like spiritual beings may inhabit these places and react to human presence by first getting angry and then getting "tame" as humans permanently occupy the place. This expresses again the idea of "extra-human intentionality." For a review of Bolivian Andean beliefs in such creatures, see Spedding (1992).

\section{Adaptations to climatic risks}

How do Andean farmers adapt to increasingly unpredictable and changing weather conditions that they perceive? A common land use practice is to disperse cultivated plots across the community's territory. Figure 2 shows the location of plots of five households from Chorojo. Instead of a single continuous plot, most people cultivate parcels scattered across the community's land, at different elevations and on different aspects. They clearly identify the function of this strategy as risk reduction:

Fig. 2. Location of cultivation plots in Chorojo.

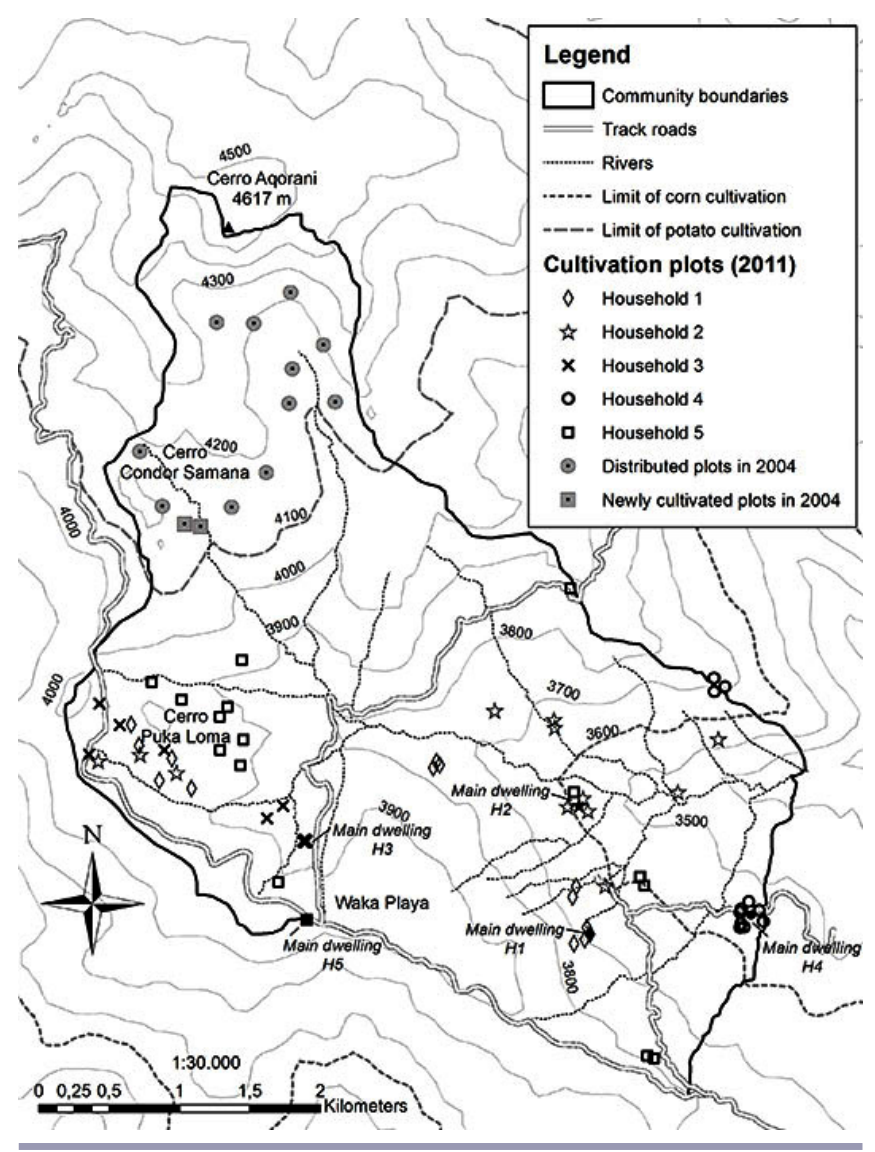

My land is everywhere. It is down there, over there too, on that peak, I have in Chimpa Chica [the opposite hillside]; I have plots everywhere. Because some parts do not produce and other produce well, that is why. (M, aged 42, Chorojo) 
Figure 2 also shows the lands that were distributed above 4100 $\mathrm{m}$ and the plots that were opened up at $4150 \mathrm{~m}$. These plots started in 2004 on a communal decision to take the opportunity of producing potatoes of better quality and free of disease:

In higher areas, we can get even better harvests, because up there, there are no pollutants yet. One year we planted there, it was 12 years ago, these lands were virgin and did not have diseases... Potatoes produced there were very tasty and floury. So again we will need to go up to the hills, so we distributed the plots among us, but we did not sow them yet. (M, aged 37, Chorojo)

However, in 2011, most plots at this altitude were left fallow. The farmers who opened up these plots explicitly qualified it as an experiment: nobody would sow all his plots at an altitude that high, where hail and frost can occur at any time during the year. Typically, a household would sow one of its 10 plots there, considering the option that it will produce good potatoes, yet taking into account the risks.

Figure 3 shows that in Chorojo, higher dwelling households tend to have the more dispersed plots. Though this trend would have to be confirmed by a larger sample, high altitude increases the risk of hail and frost, which are localized phenomena. There, dispersing parcels increases the chances to succeed in at least part of the harvest. At lower altitudes, such strategy is less crucial, and there are also more irrigated plots. In the case of Tirani (Fig. 4), most people, with the exception of two households, now dwell in the peri-urban area of the valley. All households that work less than six plots, enclosed in an oval, have jobs in the city and practice agriculture as a secondary activity only. Those who rely mainly on agriculture for their livelihoods also tend to cultivate discontinuous plots.

Fig. 3. Chorojo: number of cultivated plots of 17 households in relation with altitude.

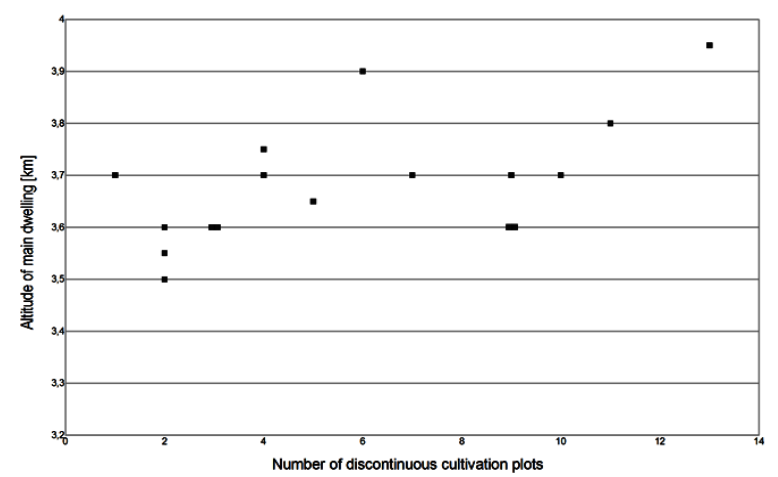

Fig. 4. Tirani: number of cultivated plots of 11 households in relation with altitude.

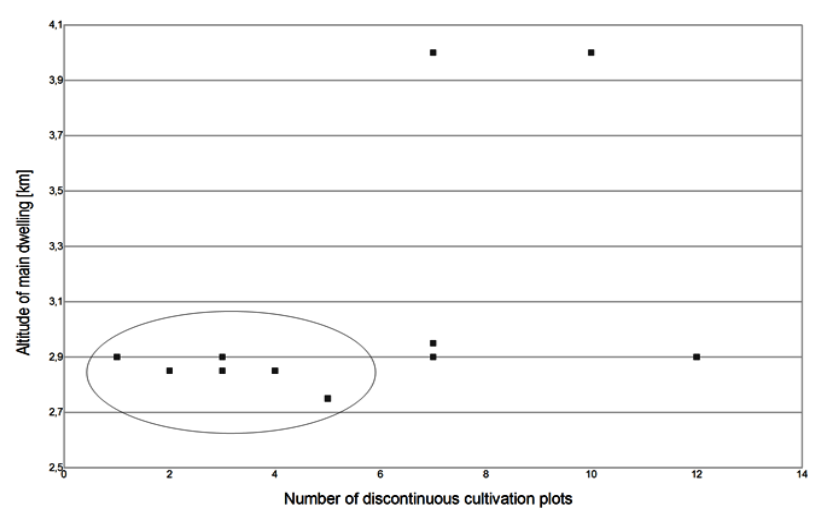

Furthermore, many people from Chorojo, and some in Tirani, believe that they can actively influence the weather in the short term with their own will and faith:

Sometimes it rains very hard and turns our field into mud, then we ask for the rain to calm ... when we do nothing and the weeds grow too much, then we think ... please calm down. (F, aged 40, Tirani)

To ask for rain, people fast together with their boy children. They walk around, near the school; they go and come back to the hills. Sometimes they sacrifice a sheep and the blood is Pachamama, this is an ancient custom from our grandfathers. (M, aged 37, Chorojo)

The second statement refers to a procession Chorojo people perform during the Christmas seasons to ask for rain. Men and boys fast and take water from the highest mountain lakes to pour it back into the village's springs, with the aim to stimulate rain.

In Chorojo and in Tirani, more recent adaptations based on external support have also appeared in the last decades, focusing mainly on the expansion of irrigation and on soil conservation. The decentralization process that started in the country in 1994 enabled the communities to increasingly request local government support for infrastructure. In Chorojo, water collection ponds have been built and PVC tubes and sprinklers have been installed with the support of the municipality of Sipe Sipe to extend the irrigation system and save water. Another project on soil conservation is being implemented by the Cochabamba provincial government and a Catholic NGO. In Tirani, soil conservation infrastructures have been built by the provincial government, and the 
community has submitted a project to the municipal government to expand the irrigation system to the highlands.

Extensive familial and social networks that reach beyond the community also help farmers to deal with the risk of harvest loss in adverse climatic conditions. These networks have existed for a long time in the area (Condarco and Murra 1987). Currently, most people from both communities have relatives living in other parts of the Cochabamba region like the towns of Sipe Sipe and Quillacollo, or the Chapare lowlands where they sometimes own land as well. They rely on their networks of numerous godfathers chosen among wealthier families in the town or the city for economic support.

Finally, off-farm labor and out-migration are important household strategies in the area. In both communities, most people do not rely completely on their harvest for their livelihoods. Insufficient access to land is often mentioned as a reason to migrate. In Tirani most people have access to seasonal jobs in the city in case of crop failure. They can take jobs in the city without migrating, but have been increasingly giving up agriculture because of afforestation linked to the implementation of the Tunari national park (Boillat et al. 2008). In Chorojo, only one or two young adults per households stay in the community and usually migrate seasonally. Permanent migration to the nearby town of Sipe Sipe has increased during the last decade because of better education, services, as well as job opportunities in construction, transportation, trade, and even municipal government. Nevertheless, permanent migrants very rarely sell their land and usually go back to their community to work their plots during sowing and harvest time, or rent them.

\section{DISCUSSION}

People of Chorojo and Tirani clearly observed changes in weather phenomena and biota distribution, presumably related to global climate change. Their observations rely on their personal experience and are more detailed than science and media discourse on global climate change (Marin and Berkes 2013). People's general observations of change were consistent with scientific observations (Perez et al. 2010, Marengo et al. 2011), and went beyond merely temperature increases to include unpredictability of rainfall, increase of extreme events, and incidence of pests. The observed changes and impacts varied with altitude: at higher altitudes, the main concern was increasing frequency of storms and hail causing crop damage; at lower altitudes (the valley) it was drought and the overall availability of water. A general concern was the concentration of the rainy season within a shorter period, also observed by other farmers (Tapia et al. 2012) and scientists (Ticehurst et al. 2009).

The Quechua have diverse interpretations to make sense of climate change. However, these interpretations shared the idea of associating climate change with other kinds of change, i.e., cultural and environmental changes, such as loss of customs, population growth, out-migration, urbanization, and land degradation. They seemed to regard the various phenomena of change as being related, as also noted with some other indigenous groups (Peloquin and Berkes 2009). Quechua observations can be summarized in three points.

First, the farmers did not consider climate change as an isolated phenomenon. Rather, they tended to associate it with other social and environmental changes observed, such as loss of values and urbanization. Some answers to the question why change is occurring linked changes directly to human moral and spiritual behavior, while others made the link between change and environmental behavior. Even in the latter case, however, farmers did not mention or seek global causes for the problem, but rather looked for local causes and associations.

Second, some people did not consider climate change as an unknown and unprecedented phenomenon but interpreted it as part of a cycle. This included a belief in the return of some characteristics of ancient times, but also mythical references to both Christian and "Incan Utopia" millenarianism, ideologies that have a long history in the Andean cultural context (Flores Galindo et al. 2010). These interpretations suggest that people seek clues about what is happening within the deepest part of their collective social memory, historical or mythical, and often idealized. This "return of idealized ancient times" idea might be worth exploring further in studying Quechua and other indigenous perceptions of change.

Third, environmental phenomena were interpreted as the expression of "extra-human intentionalities." In this case environmental change is related to a reaction of natural or spiritual entities that the Quechua of Chorojo and Tirani consider to have life-like characteristics (Boillat et al. 2013; also compare with Miller and Davidson-Hunt 2010). Associating phenomena with the agency of natural or spiritual entities can be interpreted as knowledge that addresses multiple and complex causes of phenomena. In this sense, Quechua indigenous knowledge interprets complex causality, focusing on the meaning rather than on the detailed explanation of a phenomenon (Rist and Dadouh-Guebas 2006). Similar concepts of causality are also found among other indigenous groups (Berkes 2012a). Thus rather than trying to provide reductionist cause-effect explanations for climate change, as Western science often does, indigenous knowledge acknowledges uncertainty and unpredictability, and recognize natural cycles (Peloquin and Berkes 2009).

Although the small sample does not allow identifying differences in knowledge by age-group and gender, expressions of the indigenous patterns of interpretation were common among "community experts" who include all age groups and gender, even in the peri-urban community of Tirani where people are in close contact with modern science and 
mass media. The question of whether these patterns of interpretation are used by less knowledgeable or less interested people remains open. Nevertheless, climate change does not seem to have challenged traditional knowledge; different agegroups and gender are clearly recreating their knowledge using their own mental models, understood as their specific way of representing the world, and are likely to influence each other. These models include the observation of many variables that go beyond climatic and biological observations to include people's own assessment of social aspects, a worldview governed by the agency of spiritual entities and the relationships with them, and an active inquiry into the collective social memory.

These considerations highlight the importance of traditional knowledge to assess and adapt to climate change. On the one hand, a reason for the persistence of indigenous interpretations may be that climate science, poorly developed in Bolivia and ill-suited to explain extreme local variability in the Andes (Sherwood and Bentley 2009) is simply not satisfactory. On the other hand, traditional knowledge and belief is livelihoodoriented and integrative. Linking climate change with social and spiritual values might be at odds with scientific interpretations. However, such interpretations help people to address and deal with the complex interplay between climatic, ecological, social, economic, and political change. In this regard, there were some parallels with the climate change sense-making of Mongolian herders (Marin 2010), as well as with the Inuit observations of weather variability and unpredictability (Weatherhead et al. 2010). Furthermore, indigenous ways of observing do not seem to have been challenged by climate change. This highlights the significance of considering traditional knowledge as process rather than as content (Berkes 2009) and acknowledge its dynamic and integrative nature.

How do these findings relate to the ability of the Quechua to cope with, prepare for, and/or adapt to disturbance and uncertain social-ecological conditions, i.e., their adaptive capacity (Armitage 2005)? Andean farmers have learned to live with change and uncertainty; their adaptations that deal with the interannual variability of rainfall are impressive. These adaptations have been practiced for a long time in the area and include anticipating/forecasting the next season's rainfall and making agricultural decisions accordingly (Orlove et al. 2002); and dispersing sowing in time and space, and accessing plots at different altitudes and aspects (Campbell and Godoy 1986, Morlon 1992).

Successful past adaptation, however, is not the same as adaptive capacity to deal with new changes. Fundamental components of adaptive capacity include the ability for social learning and ability to experiment (Armitage and Plummer 2010). A small number of people are in fact experimenting with ways of taking advantage of higher temperatures by planting potatoes beyond their previous altitude limits. These are the people who dwell in the highest areas, and who are the local experts in the traditional knowledge of farming at the margins. Beliefs that associate climate change with other kinds of change might be an important component for social learning in the communities, because observed changes can contribute to internal reflection processes on social organization and values (Rist et al. 2007).

Communities are learning to expand their social networks and access external support for nontraditional adaptations, such as expanded irrigation systems using modern technology, thus clearly combining different types of knowledge. Being indigenous seems no longer to be a barrier to access support for these adaptation measures. The Bolivian government is taking seriously the need to support peasant and indigenous communities to adapt to climate change, but we consider it too early to assess how the political will to help is translated into practice.

Out-migration and off-farm labor as adaptations are more controversial. First, as observed by Tacoli (2009) in other contexts, climate change is rarely the main reason to migrate. Rather, socioeconomic factors like the attraction to the town, land access issues, and protected area enforcement in the case of Tirani play key roles. Second, different types of migration have different outcomes. Definitive migration to big cities has been deemed a worst-case scenario (Bolin 2009). However, in our study area migration is mainly oriented to small towns and linked with local empowerment; it involves income diversification without complete abandonment of farming. This strategy can be interpreted as an adaptation to cope with livelihood risks and to expand social networks, which can help to lower pressure on local resources and enable investments (Tacoli 2009). In that case one has to ask whether an aging workforce threatens community institutions, and whether less time spent on farming threatens knowledge transmission. Studies with larger samples could help address these questions.

\section{CONCLUSION}

Indigenous peoples living in extreme environments like the Andes have a long record of knowledge creation to deal with risk and uncertainty. In our area of study, climate change does not seem to have challenged indigenous knowledge. Rather, people are interpreting change using their own traditional representations of the world. Far from taking climate change in a fatalistic way as a given, people are seeking meaning, and designing adaptations using their own knowledge. They do not seek solutions aimed at adapting to climate change alone, but rather holistic solutions to increase their resilience to a wide range of shocks and stresses from various sources (Berkes 2012b). Thus our results support Salick and Ross's (2009) contention that the assumption of "helpless indigenous victims" in the face of climate change must be challenged. 
Adaptations hinge upon these indigenous ways of interpreting change, which may be summarized as: holding knowledge based on personal experience and practice; focusing on associations between phenomena, making analogies between natural phenomena and living beings; interpreting phenomena as parts of natural cycles, and drawing from past experiences. These considerations make traditional knowledge an important resource to enhance adaptive capacity. In this case, knowledge must be acknowledged as process, emphasizing ways of observing, discussing and interpreting new information. Problem-oriented coproduction of knowledge can take place if both indigenous people and scientists recognize that their knowledge is partial, and apparent contradictions are solved if knowledge is not taken out of its cultural context (Berkes 2012a). Furthermore, collaboration between indigenous and scientific knowledge to address more precise time frames of change could be explored.

Whether traditional and nontraditional adaptations described above will lead to successful adaptation strategies will not only depend on the extent of the impact of future climate change, but also on other kinds of change that the communities are facing. These include increasing economic attraction of urban centers, land access issues, and protected area enforcement, which might lead to increased out-migration from the communities and abandonment of farming. Therefore, efforts aimed at enhancing the resilience of the communities should take an integrative approach to these issues. Although it might be difficult or counterproductive to curb out-migration, efforts should focus on enabling families to spend reasonable time in farming, as well as enhancing cooperation and mutual learning between community people and their town-dwelling or urban relatives.

Responses to this article can be read online at: http://www.ecologyandsociety.org/issues/responses. php/5894

\section{Acknowledgments:}

We are thankful to the villagers of Chorojo and Tirani, who kindly accepted to answer our questions on how they perceive changes. We also thank our senior field assistants and translators, Felix Quiroga and Elvira Serrano, without whom a deep insight into farmers' perceptions would not have been possible. Boillat's stay at the University of Manitoba has been supported by the Swiss National Science Foundation's (SNSF) Prospective Researchers Program (Grant PBBEP1_135314). His fieldwork in Bolivia in 2011 was supported jointly by the SNSF, the Swiss National Centre of Competence in Research North-South (http://www.north-south.unibe.ch/), and the University of Manitoba. Berkes' work has been supported by the Social Science and Humanities Research Council of
Canada and the Canada Research Chairs Program (http:// www.chairs-chaires.gc.ca/).

\section{LITERATURE CITED}

Armitage, D. 2005. Community-based narwhal management in Nunavut, Canada: change, uncertainty, and adaptation. Society \& Natural Resources 18(8):715-731.

Armitage, D., and R. Plummer, editors. 2010. Adaptive capacity and environmental governance. Springer-Verlag, Berlin and Heidelberg, Germany. http://dx.doi. org/10.1007/978-3-642-12194-4

Berkes, F. 2009. Indigenous ways of knowing and the study of environmental change. Journal of the Royal Society of New Zealand 39(4):151-156. http://dx.doi.org/10.1080/03014220909510568

Berkes, F. 2012a. Sacred ecology. Third Edition. Routledge, New York, New York, USA.

Berkes, F. 2012b. Understanding uncertainty and reducing vulnerability: lessons from resilience thinking. Pages 27-44 in C. E. Haque and D. Etkin, editors. Disaster risk and vulnerability. McGill-Queen's University Press, Montréal, Québec, Canada.

Berkes, F., and D. Armitage. 2010. Co-management institutions, knowledge, and learning: adapting to change in the Arctic. Etudes/Inuit/Studies 34:109-131. http://dx.doi. org/10.7202/045407ar

Berkes, F., J. Colding, and C. Folke. 2000. Rediscovery of traditional ecological knowledge as adaptive management. Ecological Applications 10(5):1251-1262. http://dx.doi. org/10.1890/1051-0761(2000)010[1251:ROTEKA]2.0.CO;2

Boillat, S. 2007. Traditional ecological knowledge, land use and ecosystem diversity in the Tunari National Park (Bolivia). An ethnoecological approach to dialogue between traditional and scientific ecological knowledge. Dissertation. University of Bern, Bern, Switzerland.

Boillat, S., S. Rist, E. Serrano, D. Ponce, and J. Delgadillo. 2008. Struggling 'ontological communities': transformations of conservationists' and peasants' discourses in the Tunari National Park in Bolivia. Pages 37-80 in M. Galvin and T. Haller, editors. People, protected areas and global change: participatory conservation in Latin America, Africa, Asia and Europe. Geographica Bernensia, Bern, Switzerland.

Boillat, S., E. Serrano, S. Rist, and F. Berkes. 2013. The importance of place names in the search for ecosystem-like concepts in indigenous societies: an example from the Bolivian Andes. Environmental Management 51(3):663-678. http://dx.doi.org/10.1007/s00267-012-9969-4 
Bolin, I. 2009. The glaciers of the Andes are melting: indigenous and anthropological knowledge merge in restoring water resources. Pages 228-239 in S. A. Crane and M. Nuttall, editors. Anthropology and climate change: from encounters to actions. Left Coast Press, Walnut Creek, California, USA.

Bottazzi, P., and S. Rist. 2012. Changing land rights means changing society: the sociopolitical effects of agrarian reforms under the government of Evo Morales. Journal of Agrarian Change 12(4):528-551. http://dx.doi.org/10.1111/ j.1471-0366.2012.00367.x

Campbell, B., and R. A. Godoy. 1986. Commonfield agriculture: the Andes and medieval England compared. Pages 323-358 in D. Bromley, D. H. Feeny, J. L. Gilles, W. T. Gladstone, B. J. Lausche, M. A. McKean, R. J. Oakerson, E. Ostrom. P. E. Peters, C. F. Runge, J. T. Thomson, editors. Proceedings of the Conference on Common Property Resource Management (Annapolis, 1985). National Academy Press for the National Research Council, Washington, D.C., USA.

Chirveches, M. 2006. Percepción campesina del clima y gestión de riesgo en la actividad agropecuaria en el Parque Nacional Tunari. El caso de las comunidades de Tirani (municipio de Cercado) y Chorojo (municipio de Sipe Sipe). Thesis. AGRUCO-Universidad Mayor de San Simón, Cochabamba, Bolivia.

Condarco, R., and J. Murra. 1987. La teoría de la complementariedad vertical eco-simbiótica. HISBOL, La Paz, Bolivia.

Flores Galindo, A., H. Willie, C. F. Walker, and C. Aguirre. 2010. In search of an Inca: identity and utopia in the Andes. Cambridge University Press, Cambridge, UK.

Folke, C., J. Colding, and F. Berkes. 2003. Synthesis: building resilience and adaptive capacity in social-ecological systems. Pages 352-387 in F. Berkes, J. Colding, and C. Folke, editors. Navigating social-ecological systems. Cambridge University Press, Cambridge, UK. http://dx.doi.org/10.1017/ CBO9780511541957.020

Gottfried, M., H. Pauli, A. Futschik, M. Akhalkatsi, P. Barancok, J. L. B. Alonso, G. Coldea, J. Dick, B. Erschbamer, M. R. Fernández Calzado, G. Kazakis, J. Krajci, P. Larsson, M. Mallaun, O. Michelsen, D. Moiseev, P. Moiseev, U. Molau, A. Merzouki, L. Nagy, G. Nakhutsrishvili, B. Pedersen, G. Pelino, M. Puscas, G. Rossi, A. Stanisci, J.-P. Theurillat, M. Tomaselli, L. Villar, P. Vittoz, I. Vogiatzakis, and G. Grabherr. 2012. Continent-wide response of mountain vegetation to climate change. Nature Climate Change 2:111-115. http://dx. doi.org/10.1038/nclimate1329

Gustafson, B. 2009. New languages of the state: indigenous resurgence and the politics of knowledge in Bolivia (Narrating Native Histories). Duke University Press, Durham, North Carolina, USA.
Healey, S. 2009. Ethno-ecological identity and the restructuring of political power in Bolivia. Latin American Perspectives 36(4):83-100. http://dx.doi.org/10.1177/00945$\underline{82 X 09338590}$

Intergovernmental Panel on Climate Change (IPCC) 2007. Climate change 2007: synthesis report. Contribution of Working Groups I, II and III to the Fourth Assessment Report of the Intergovernmental Panel on Climate Change. Core Writing Team, R. K. Pachauri, and A. Reisinger, editors. IPCC, Geneva, Switzerland. [online] URL: http://www.ipcc. ch/publications and data/publications ipcc fourth assessment_report_synthesis_report.htm

Leichenko, R., and K. O'Brien. 2008. Environmental change and globalization: double exposures. Oxford University Press, New York, New York, USA. http://dx.doi.org/10.1093/ acprof:oso/9780195177329.001.0001

Lynam, T., and K. Brown. 2011. Mental models in humanenvironment interactions: theory, policy implications, and methodological explorations. Ecology and Society 17(3): 24. http://dx.doi.org/10.5751/ES-04257-170324

Marengo, J. A., J. D. Pabón, A. Díaz, G. Rosas, G. Ávalos, E. Montealegre, M. Villacis, S. Solman, and M. Rojas. 2011. Climate change: evidence and future scenarios for the Andean region. Pages 110-127 in S. Herzog, R. Martinez, P. M. Jorgensen, and $\mathrm{H}$. Tiessen, editors. Climate change and biodiversity in the tropical Andes. IAI-SCOPE-UNESCO, Paris, France.

Marin, A. 2010. Riders under storms: contributions of nomadic herders' observations to analysing climate change in Mongolia. Global Environmental Change 20:162-176. http:// dx.doi.org/10.1016/j.gloenvcha.2009.10.004

Marin, A., and F. Berkes. 2013. Local people's accounts of climate change: to what extent are they influenced by the media? Wiley Interdisciplinary Reviews: Climate Change 4:1-8. http://dx.doi.org/10.1002/wcc.199

Miller, A. M., and I. Davidson-Hunt. 2010. Fire, agency and scale in the creation of aboriginal cultural landscapes. Human Ecology 38:401-414. http://dx.doi.org/10.1007/s10745-010-9325-3

Morlon, P. 1992. Comprendre l'agriculture paysanne dans les Andes centrales. INRA Editions, Paris, France.

Nakashima D. J., K. Galloway, M. McLean, H. D. Thrulstrup, A. Ramos Castillo, and J. Rubis. 2012. Weathering uncertainty: traditional knowledge for climate change assessment and adaptation. UNESCO, Paris, France.

Navarro, G., and M. Maldonado. 2002. Geografía ecológica de Bolivia, vegetación y ambientes acuáticos. Centro de Ecología Simón I. Patiño, Santa Cruz de la Sierra, Bolivia. 
Orlove, B. S., J. C. H. Chiang, and M. A. Cane. 2002. Ethnoclimatology in the Andes: a cross-disciplinary study uncovers a scientific basis for the scheme Andean potato farmers traditionally use to predict the coming rains. American Scientist 90:428-435.

Ovuka, M., and S. Lindqvist. 2000. Rainfall variability in Murang'a district, Kenya: meteorological data and farmers' perception. Geografiska Annaler Series A. Physical Geography 82:107-119. http://dx.doi.org/10.1111/ j.0435-3676.2000.00116.x

Peloquin, C., and F. Berkes 2009. Local knowledge, subsistence harvests, and social-ecological complexity in James Bay. Human Ecology 37:533-545. http://dx.doi. org/10.1007/s10745-009-9255-0

Perez, C., C. Nicklin, O. Dangles, S. Vanek, S. Sherwood, S. Halloy, K. Garrett, and G. Forbes. 2010. Climate change in the high Andes: implications and adaptation strategies for small-scale farmers. International Journal of Environmental, Cultural, Economic and Social Sustainability 6(5):71-88.

Raj, R. 2006. Harmonizing traditional and scientific knowledge systems in rainfall prediction and utilization. Pages 225-239 in W. V. Reid, F. Berkes, T. Wilbanks, and D. Capistrano, editors. Bridging scales and knowledge systems. Island Press, Washington, D.C., USA.

Reed, M. S., A. C. Evely, G. Cundill, I. Fazey, J. Glass, A. Laing, J. Newig, B. Parrish, C. Prell, C. Raymond, and L. C. Stringer. 2010. What is social learning? Ecology and Society 15(4): r1. [online] URL: http://www.ecologyandsociety.org/ vol15/iss4/resp1/

Rist, S., M. Chidambaranathan, C. Escobar, U. Wiesmann, and A. Zimmermann. 2007. Moving from sustainable management to sustainable governance of natural resources: the role of social learning process in rural India, Bolivia and Mali. Journal of Rural Studies 23:23-37. http://dx.doi. org/10.1016/j.jrurstud.2006.02.006

Rist, S., and F. Dadouh-Guebas. 2006. Ethnosciences - a step towards the integration of scientific and indigenous forms of knowledge in the management of natural resources for the future. Environment, Development and Sustainability 8:467-493. http://dx.doi.org/10.1007/s10668-006-9050-7

Salick, J., and N. Ross. 2009. Traditional peoples and climate change. Global Environmental Change 19:137-139. http://dx. doi.org/10.1016/j.gloenvcha.2009.01.004

Sherwood, S., and J. Bentley. 2009. Katalysis: helping Andean farmers adapt to climate change. Participatory Learning and Action 60:65-75.

Smit, B., and J. Wandel. 2006. Adaptation, adaptive capacity and vulnerability. Global Environmental Change 16:282-292. http://dx.doi.org/10.1016/j.gloenvcha.2006.03.008
Spedding, A. 1992. Almas, anchanchus y alaridos en la noche: el paisaje vivificado de un valle Yungueño. Pages 299-330 in S. Arze, editor. Etnicidad, economía y simbolismo en los Andes. Hisbol-IFEA-SBH-ASOR, La Paz, Bolivia.

Tacoli, C. 2009. Crisis or adaptation? Migration and climate change in a context of high mobility. Environment and Urbanization 21(2):513-525. http://dx.doi.org/10.1177/0956247809342182

Tapia, N., D. Torrico, M. Chirveches, and A. Machaca. 2012. Indicadores del tiempo y la predicción climática. Estrategias agroecológicas campesinas para la adaptación al cambio climático en la puna cochabambina. Fundación PIEB, La Paz, Bolivia.

Ticehurst, S., S. Urgel, and S. Best. 2009. Bolivia. Cambio climático, pobreza y adaptación. Oxfam Internacional, La Paz, Bolivia.

Tobias, T. N. 2000. Chief Kerry's moose. A guidebook to land use and occupancy mapping, research design and data collection. Union of BC Indian Chiefs/Ecostrust Canada, Vancouver, Canada.

Turner, B. L. II, R. E. Kasperson, P. A. Matson, J. J. McCarthy, R. W. Corell, L.y Christensen, N. Eckley, J. X. Kaspersonb, A. Luers, M. L. Martello, C. Polsky, A. Pulsipher, and A. Schiller. 2003. A framework for vulnerability analysis in sustainability science. Proceedings of the National Academy of Sciences of the United States 100:8074-8079. http://dx.doi. org/10.1073/pnas.1231335100

Tyler, N. J. C., J. M. Turi, M. A. Sundset, K. Strøm Bull, M. N. Sara, E. Reinert, N. Oskal, C. Nellemann, J. J. McCarthy, S. D. Mathiesen, M. L. Martello, O. H. Magga, G. K. Hovelsrud, I. Hanssen-Bauer, N. I. Eira, I. M. G. Eira, R. W. Corell. 2007. Saami reindeer pastoralism under climate change: applying a generalized framework for vulnerability studies to a sub-arctic social-ecological system. Global Environmental Change 17:191-206. http://dx.doi.org/10.1016/ j.gloenvcha.2006.06.001

Van den Berg, H. 1990. La tierra no da así no más. Los ritos agrícolas en la religión de los aymara-cristianos. Hisbol, La Paz, Bolivia.

Vuille, M., B. Francou, P. Wagnon, I. Juen, G. Kaser, B. G. Mark, and R. S. Bradley. 2008. Climate change and tropical Andean glaciers: past, present and future. Earth Science Reviews 89:79-96. http://dx.doi.org/10.1016/j.earscirev.2008.04.002

Wachtel, N. 1981. Los Mitimaes del valle de Cochabamba: la política de colonización de Wayña Capac. Historia Boliviana (Cochabamba): ii:21-57.

Weatherhead, E., S. Gearheard, and R. G. Barry. 2010. Changes in weather persistence: insight from Inuit knowledge. Global Environmental Change 20:523-528. http://dx.doi. org/10.1016/j.gloenvcha.2010.02.002 